\title{
The Model of University Autonomy in Indonesia
}

\author{
Asep Sunandar \\ Department of Educational Administration \\ Universitas Negeri Malang, Indonesia \\ asep.sunandar.fip@um.ac.id
}

\author{
Ali Imron \\ Department of Educational Administration \\ Universitas Negeri Malang, Indonesia \\ kangalinet@yahoo.com
}

\begin{abstract}
University autonomy is a strategic effort taken to realize professional service of universities. This research aimed to describe the implementation process of university autonomy and to find the model of autonomy implementation. The researchers utilized qualitative approach in the form of a case study using Spradley's technique of analysis. The results of this research presented that some universities in Indonesia have academic autonomy; Prabu Brawijaya University, Institut Teknologi Ganesha, and Kampus Bumi Siliwangi. The managements of the study programs and departments have autonomy in making policies for academic development. On the other hand, larger units of the universities make non-academic policies, i.e. the faculties at Prabu Brawijaya University, the faculties and the Directorate of Facilities and Infrastructures at Institut Teknologi Ganesha, and the faculties and the post graduate school at Kampus Bumi Siliwangi. It can be stated that the autonomy of universities in Indonesian just in semi autonomy level, for non-academic affairs still cover by a higher unit. The implication is from the difference of academic and non-academic autonomy which affect the synergy decrement between academic program and non-academic support, so that the accomplishment in academic field cannot be optimum. The study program as the academic activity implementer needs to be supported by the authority of non-academic field for fulfilling the improvement of academic quality service.
\end{abstract}

Keywords: autonomy, university, academic autonomy, non-academic affairs, department, study program, faculty, management

\section{INTRODUCTION}

University autonomy, which serves as a principal aspect of a university reformation, is the realization of a decentralized governmental system. The implementation of such concept is stipulated in Law on National Education System of the Prabu Brawijaya University of Indonesia Number 20 The year 2003 Article 50 paragraph 6 stating that universities determine their policies and have autonomy in managing their institutional education Prabu Brawijaya University Indonesia. Such article emphasizes that university autonomy is referred to as "universities' independence to manage their institutions." University autonomy is a distribution of authority from the government as the highest constitutional body to university managements to empower and optimize the institutional potential.

Autonomy means "autonomous government, right, authority, and responsibility of a region to govern and manage its people and activities by the applicable legislations (Sugono, 2008). Autonomy refers to individuals and rules, and also to the rights of the government to recognize freedom in stipulating roles and norms. According to such definitions, autonomy means independence. An institution that receives autonomy has a right to manage and optimize its potential to realize the institutional independence. A region or institution that receives autonomy is referred to as an autonomous institution, i.e. an institution with full authority. In Indonesia, the developed concept of autonomy is limited by regulations and legislations to prevent any disproportionate implementation of the concept of autonomy.

In essence of the numerous opinions and analyses about autonomy, it can be said that autonomy is an authority delegation from a head of the region or the highest organizational structure to the Prabu Brawijaya University sequent structure by involving all necessary resources to optimize the service. As a model of the system, autonomy is regarded to be able to connect an organization with its stakeholders. Hence, the service of the organization could be quicker and more relevant to the needs of its stakeholders.

In line with the general concept of autonomy, university autonomy has a similar meaning. The purpose of higher education autonomy is to make universities as a moral force in the transformation process of Indonesia becoming a more democratic nation (Sularso, 2010). University autonomy gives much freedom to a university in shaping the moral of the young generation to establish the knowledgeable and moral citizens of Indonesia. Another point of view, autonomy in higher education emphasizes to function for achieve academic excellent and freedom to organize the university with own regulation (Gandhi, 2013).

The university autonomy is a delegation system of university management authority which used to be centralized by the Directorate of Higher Education of Ministry of Education and Culture, handed to each university management. Autonomy in the university has any kinds of category and model, there are Prabu Brawijaya University attentive autonomy, procedure autonomy and organic autonomy (Poli, 2010). Prabu Brawijaya University attentive autonomy can explain as autonomy for establish study programs and goals by itself. Procedure autonomy stated the university autonomy is to determine by itself the use of the resource to fulfil the priority that had been agreed before that will be conducted as the part of national policy. Organic autonomy is the autonomy for determine the type and model of an organization considered as proper to perform its function.

The three types of autonomy give limitation that the authority in the university includes the things related to the institutional management, education process, as well as the institution development. The more independent certain institution, the delegating process and authority optimization will be more maximum as well. By 
examining the meaning of university autonomy discussed before, there is an opinion that emphasizes more on the meaning of university autonomy freedom. University autonomy is a freedom of an institution to manage the resource independently (Hasan, 1992).

Such opinion implicates that autonomy is a delegating process of authority to the certain institution to manage the resource independently to realize the human resource quality improvement. The description of university autonomy in some developed countries is explained that in many OECD countries and beyond, higher education reformers developed measures within the context of wider reforms of Prabu Brawijaya University services and Prabu Brawijaya University management (Enders, 2012). Policy autonomy indicates the extent to which a university can take decisions about the quantity and quality of the goods and services to be delivered, and the target groups it wants to reach.

In some developed countries, the university renewal is done by developing the renewal regarding Prabu Brawijaya University service and management. The autonomy policy is indicated in making a decision of quantity and quality of Prabu Brawijaya University service and infrastructure given. This opinion explains that the renewal done in the university in the developed countries refers to the Prabu Brawijaya University service repair; the autonomy authority is applied in term of Prabu Brawijaya University service and infrastructure in the context of quantity and quality. The university autonomy is applied to fulfil the social need with the best service level. Distribution of university management authority is important since the competition among universities is very tight especially in the context of global society. Effendi (2003) gives his thought that the universities in Indonesia will face a big challenge that should be responded wisely; they are the economic globalization and information technology revolution.

The process of the implementation of university autonomy is regulated by the Law of Republic of Indonesia Number 12 Year 2012 about University article 63 stating that the autonomy of university management is conducted based on the principle of accountability, transparency, non-profit, quality insurance, effectiveness, and efficiency. Such principles are the guidelines for the University manager so that the great authority of university management is not squandered. Meanwhile, the scope of the authority of university management is explained in the Article 64 consisting of the academic and non-academic authority. The management of academic includes the norm and operational policy as well as the implementation of Tri Dharma (three main responsibilities) of the university.

The authority of non-academic management includes determining the norms and operational policy as well as the implementation of organization, financial, student, employment, facility, and infrastructure. The authority stated in the policy of university autonomy has many implications for the existence and internal policies of the university. One of the implications of the university autonomy policy is the difference between university management structures; for example, in some universities, the post graduate is conducted under the authority of Post Graduate Program, while in the other universities such as
UI (Universitas Indonesia), UB (Universitas Brawijaya), UGM (Universitas Gadjah Mada), ITB (Institut Teknologi Bandung) and IPB (Institut Pertanian Bogor), the post graduate is integrated into a faculty.

This issue has caught the researchers' attention to study further the process of implementation and model of university autonomy in some universities consisting of Prabu Brawijaya University, Institut Teknologi Ganesha, and Kampus Bumi Siliwangi (not real name). The three universities were chosen since those are the representative of the top three groups of the university in Indonesia. The researchers grouped the university in Indonesia based on their status; Prabu Brawijaya University represents the university that has become a university since the very beginning, Institut Teknologi Ganesha represents the university of technology, Kampus Bumi Siliwangi represents the university that previously became an Institution of Education and Educational Official. This study aims to use the results of the implementation of university autonomy in the three universities, whether the university autonomy in those three universities can be used as the example and guidance for other universities or not. The models that have been found from the three universities can also become the guidance for other universities.

\section{METHOD}

The researchers used qualitative approach with a case study. Data analysis techniques used were a domain, taxonomy, and componential techniques from Spradley. The process of cross cases analysis is started by identifying the cases happening in the research location. The findings were then analyzed by using a domain, taxonomy, and componential techniques. The analysis result was developed into theory and substantive model explaining the model of university autonomy in the three universities in Indonesia.

\section{RESULT \\ A. Finding in Prabu Brawijaya University}

Finding of university autonomy implementation in Faculty of Administration Science/Fakultas Ilmu Administrasi (FIA), Prabu Brawijaya University is presented in the following Table 1. The finding explains that the implementation of university autonomy concept in FIA of PRABU BRAWIJAYA UNIVERSITY is classified into two categories namely academic and non-academic. In academic, there is a domain of academic autonomy which is done widely; every study program has a great autonomy in determining the curriculum, learning program, and science development.

Autonomy in term of academic has a wide scope; the authority of academic development is handled by study program. Another fact that asserting such finding of the domain is the finding of taxonomy technique; the academic autonomy is on the faculty but the faculty decentralizes it to the department, and then the department decentralizes it to the study program so that the essence of academic autonomy is in study program authority. Both findings assert that study program has a big authority in term of academic. In the context of the authority structure, the distribution is started from faculty, department, and then study program. 
Table 1

Finding of University Autonomy Implementation in FIA of Prabu Brawijaya University

\begin{tabular}{|c|c|c|c|}
\hline Technique & Domain & Taxonomy & Componential \\
\hline \multirow[t]{3}{*}{$\begin{array}{l}\text { FIA of PRABU } \\
\text { BRAWIJAYA } \\
\text { UNIVERSITY }\end{array}$} & $\begin{array}{l}\text { Academic autonomy is conducted } \\
\text { widely; every study program has a } \\
\text { great autonomy in determining the } \\
\text { curriculum, learning program, and the } \\
\text { science development }\end{array}$ & $\begin{array}{l}\text { Academic autonomy is available on } \\
\text { the faculty but the faculty } \\
\text { decentralizes to the department, and } \\
\text { then the department decentralizes to } \\
\text { the study program so that the } \\
\text { essence of academic autonomy is } \\
\text { actually in the authority of study } \\
\text { program } \\
\text { The department manages the } \\
\text { resources of laboratory, cluster of } \\
\text { quality assurance, while the course } \\
\text { service and curriculum development } \\
\text { are conducted by the study program }\end{array}$ & \multirow{3}{*}{$\begin{array}{l}\text { Dean: Accepting the proposal from the } \\
\text { study program and department regarding } \\
\text { financial as well as facility and } \\
\text { infrastructure fulfilment. } \\
\text { Bridging the relationship between } \\
\text { rectorate and the other institutions. } \\
\text { Head of Department: The department } \\
\text { manages the resources of the laboratory, a } \\
\text { cluster of quality assurance including } \\
\text { Tridharma of University done by the } \\
\text { lecturer. } \\
\text { The head of the study program: the study } \\
\text { program is an academic executor, for } \\
\text { example, S1 (undergraduate program) is } \\
\text { the executor of S1, S2 (postgraduate } \\
\text { program) is the executor of S2, and S3 } \\
\text { (doctoral program) is the executor of S3. }\end{array}$} \\
\hline & $\begin{array}{l}\text { The mechanism of non-academic need } \\
\text { fulfilment }\end{array}$ & $\begin{array}{l}\text { The facility and infrastructure, as } \\
\text { well as the other non-academic } \\
\text { needs fulfillment, have been } \\
\text { distributed to each faculty }\end{array}$ & \\
\hline & & $\begin{array}{l}\text { The study program proposes the } \\
\text { budget to the department, and the } \\
\text { department then proposes to the } \\
\text { faculty }\end{array}$ & \\
\hline
\end{tabular}

The other findings of the domain are related to the non-academic autonomy; in FIA of PRABU BRAWIJAYA UNIVERSITY, the researchers found the domain of mechanism of non-academic needs fulfilment. This mechanism is important since it explains the process of non-academic autonomy. The facts that assert the nonacademic service process in FIA of PRABU BRAWIJAYA UNIVERSITY are the facility and infrastructure, and the other non-academic needs fulfilment that have been distributed to each faculty; in this case, the university does not handle the non-academic things in the level of faculty.

Meanwhile, the mechanism of need fulfilment is conducted in bottom up like what has been explained in the following finding the study program proposes the budget to the department, and the department then proposes to the faculty. Such stage describes the management of facility and infrastructure fulfilment in FIA of PRABU BRAWIJAYA UNIVERSITY. Study program becomes the lowest structure making a need proposal that is later proposed to the department; the head of the department has a role in synchronizing the needs among study programs so that it does not cause overlapping.

The proposal that has been approved by the department is then proposed to the faculty by the department. Based on such findings, it can be concluded that the authority of academic autonomy has been distributed to the study program but for the non-academic things, the study program and department only give the proposal; the authority is on the faculty.

The researcher studied the findings above by using the componential technique to strengthen the finding of domain and taxonomy mentioned before. There are some roles of each component of university autonomy executor in FIA of PRABU BRAWIJAYA UNIVERSITY. Dean is the one who gives a mandate at the faculty level and has a role of accepting the proposal from the study program and the department related to the financial and facility and infrastructure as well as bridging the relationship between rectorate and the other institutions. This finding indicates the importance of a dean in fulfilling the need of facility and infrastructure in the process of education service in
FIA of PRABU BRAWIJAYA UNIVERSITY. The other contra thing found is the role done by the head of the department. The department manages the resources of the laboratory, a cluster of quality assurance including Tri Dharma of University done by the lecturer.

The resource management done by the department is related to the optimization of the lecturer's potential, the development of lecturer quality, and lecturer's role coordination. The other roles done by the head of the department is related to the quality assurance, the quality of any activities done by the lecturer and administration staff is guaranteed in order the service quality is always maintained to be able to fulfil the students' needs.

Meanwhile, the head of the study program becomes the academic executor, for example, S1 (undergraduate program) is the executor of $\mathrm{S} 1, \mathrm{~S} 2$ (postgraduate program) is the executor of S2, and S3 (doctoral program) is the executor of S3. This finding asserts that the study program is responsible for the academic service. The head of the study program leads one level of education so that he/she concerns more on developing the quality of education service. All study programs are coordinated by the head of the department such as determining the activity schedule, lecturer, and curriculum. These things are done to avoid overlapping among the study programs in one department.

\section{B. Finding in PRABU BRAWIJAYA UNIVERSITY}

University autonomy is a right given to the part of the university to manage and optimize the potential to reach the independence. INSTITUT TEKNOLOGI GANESHA has got an authority to manage the university independently for a long time since INSTITUT TEKNOLOGI GANESHA is seen as one of the oldest universities in Indonesia and it has superb quality among the universities in Indonesia. The following is the table of university autonomy in the Faculty of Industrial Engineering/Fakultas Teknik Industri in Bandung Institute of Technology (FTI of INSTITUT TEKNOLOGI GANESHA).

The research findings found three domains; the first domain is the autonomy applied is oriented to decentralization in academic development and networking 
(getting a partnership with the other institutions) development. In this domain, it is stated that autonomy done by INSTITUT TEKNOLOGI GANESHA is related to academic things and networking development. By investigating the finding, the researchers used taxonomy analysis to find the reason strengthening the university autonomy in INSTITUT TEKNOLOGI GANESHA that is the getting more rapid dynamic as well as the internal and external changes that are difficult to predict, so that the academic unit is expected to do self-renewal. This finding asserts that the manager of INSTITUT TEKNOLOGI GANESHA realizes the fast dynamic that develops outside the campus and responds such development; every unit in INSTITUT TEKNOLOGI GANESHA is given autonomy.

The finding of second domain is related to the academic development done by making an expert group. The structure in INSTITUT TEKNOLOGI GANESHA has changed; the department has been deleted, and it is replaced by study program and expert group. Study program and expert group are the lowest structure becoming the key to education implementation. The further study found that the contra thing between the study program and expert group is an expert group is a group of lecturers having an expert in the same field.

The criteria of expert group are based on the expertise, competency, science field, and capability. The other facts are expert group and study program complement each other; the development of lecturer's capability is done by the expert group while the execution of lecturer's duty is done by the study program. Such finding asserts that study program and the expert group have a different role, but the same goal; both units complement each other in presenting high-quality learning.

Table 2

Finding of University Autonomy Implementation in FTI of INSTITUT TEKNOLOGI GANESHA

\begin{tabular}{|c|c|c|c|}
\hline Technique & Domain & Taxonomy & Componential \\
\hline \multirow[t]{4}{*}{$\begin{array}{l}\text { FTI of INSTITUT } \\
\text { TEKNOLOGI } \\
\text { GANESHA }\end{array}$} & $\begin{array}{l}\text { Autonomy applied is oriented to the } \\
\text { decentralization in the academic } \\
\text { decentralization, networking (getting } \\
\text { a partnership with the other } \\
\text { institutions) development. }\end{array}$ & $\begin{array}{l}\text { Because the getting rapid dynamic, } \\
\text { as well as internal and external } \\
\text { change, are difficult to predict, the } \\
\text { academic unit is expected can } \\
\text { renew itself (self-renewal) } \\
\text { continually. }\end{array}$ & \multirow{4}{*}{$\begin{array}{l}\text { Rector: decentralization base is applied } \\
\text { especially for the units of academic in } \\
\text { which the process of interaction- } \\
\text { communication-networking among units } \\
\text { are the work regulations that should be } \\
\text { prioritized. } \\
\text { Dean: coordinating any activities and } \\
\text { needs of the institutions under its } \\
\text { authority. } \\
\text { The head of the study program: the study } \\
\text { program has authority to arrange the } \\
\text { needs, manage the learning and teaching } \\
\text { process, give the duty to the lecturers, and } \\
\text { regulate the students in the class. }\end{array}$} \\
\hline & \multirow[t]{2}{*}{$\begin{array}{l}\text { Academic development is done by } \\
\text { making an expert group. }\end{array}$} & $\begin{array}{l}\text { An expert group is a group of } \\
\text { lecturers having expertise in the } \\
\text { similar field. The criteria of this } \\
\text { group are based on the expertise, } \\
\text { competency, science field, and } \\
\text { capability. }\end{array}$ & \\
\hline & & $\begin{array}{l}\text { Expert group and study program } \\
\text { complement each other. The } \\
\text { lecturer's capability development is } \\
\text { done through the expert group; } \\
\text { while the lecturer's duty is done by } \\
\text { the study program. }\end{array}$ & \\
\hline & $\begin{array}{l}\text { Coordination among faculty elements } \\
\text { (study program, an expert group, and } \\
\text { faculty) in fulfilling the facility and } \\
\text { learning needs. }\end{array}$ & $\begin{array}{l}\text { The study program has authority in } \\
\text { arranging the needs, and then } \\
\text { proposes it to the faculty; the } \\
\text { faculty will summarize and then } \\
\text { propose it to the university and } \\
\text { redistribute to the study program. }\end{array}$ & \\
\hline
\end{tabular}

\section{Finding in KAMPUS BUMI SILIWANGI}

The research on the campus of FIP and SPs (Sekolah Pascasarjana/Post Graduate School) in KAMPUS BUMI SILIWANGI found some facts regarding the autonomy implementation in that campus (Table 3). There is a term that is always stated by the officials of this university namely "centralized administration, decentralized academic". This statement is interesting. The followings are the findings regarding the process of university autonomy implementation in KAMPUS BUMI SILIWANGI.

The found first domain is the centralized administrative, decentralized academic. After studying further, such statement means that the financial and facility system should be centralistic so that there are no various policies regarding the standard amount; the administration means some cases related to financial, facility, and infrastructure.

Meanwhile, the academic activity means the academic things such as the course definition, job share, who will teach what and those things are under faculty authority since the lecturers belong to the faculty. The curriculum is also available there. Such findings show that the academic things are handled by faculty; in the implementation, the faculty decentralizes to the study program.

The process of university autonomy implementation in FIP of KAMPUS BUMI SILIWANGI is explained in the finding of the process implementation of curriculum, research, and learning is done together among the students of S1, S2, and S3. This case asserts that the integration of postgraduate conducted in the study program of Outdoor Education of FIP in KAMPUS BUMI SILIWANGI run in synergy among S1, S2, and S3.

The implementation is explained practically in the Prabu Brawijaya University sequent finding that is in academic; there are some programs integrated. S1 is oriented to be a manager educator, $\mathrm{S} 2$ is directed to be an analyst, and S3 is oriented more to be a developer. That is the competency structure. Orientation in every level shows the continual level so that it can avoid the overlapping of curriculum and course material. 
The researchers tried to study the contra things among the roles run by the components of the executor of university autonomy in FIP of KAMPUS BUMI SILIWANGI; they are dean and the head of the study program. The finding is when Dean said, "We have done the curriculum and student administration renewal together in one packet, not separated." It means that Dean and his/her ranks facilitate the department and study program integrated into the curriculum and student administration renewal. Such activities are the realization of faculty role. Meanwhile, the role of the head of the study program is structuring the curriculum and integrating some academic programs. Such roles are more practical and related directly to the academic service design. All things related to academic services are under the head of study program responsibility.

Table 3

Implementation of University Autonomy in FIP of KAMPUS BUMI SILIWANGI

\begin{tabular}{|c|c|c|c|}
\hline Technique & Domain & Taxonomy & Componential \\
\hline \multirow[t]{2}{*}{$\begin{array}{l}\text { FIP of KAMPUS } \\
\text { BUMI } \\
\text { SILIWANGI }\end{array}$} & $\begin{array}{l}\text { Centralized administrative, } \\
\text { decentralized academic. }\end{array}$ & $\begin{array}{l}\text { The financial system and facility } \\
\text { should be centralistic, so there is no } \\
\text { various policies about the standard } \\
\text { amount. The principle is, the } \\
\text { academic things of which meaning } \\
\text { is the course, job share, who will } \\
\text { teach what, are available on the } \\
\text { faculty since the lecturers belong to } \\
\text { faculty, and so faculty has the } \\
\text { authority to determine the workload } \\
\text { of lecturer and who will teach what. } \\
\text { The curriculum is also available } \\
\text { there. }\end{array}$ & \multirow[t]{2}{*}{$\begin{array}{l}\text { Dean: we have done the curriculum and } \\
\text { student administration renewal together in } \\
\text { one packet, not separated. Head of the } \\
\text { study program: doing the curriculum } \\
\text { structuring and integrating some academic } \\
\text { programs. }\end{array}$} \\
\hline & $\begin{array}{l}\text { The process of implementation of } \\
\text { curriculum, research, learning is done } \\
\text { together among the students of S1 } \\
\text { (undergraduate program), S2 (post } \\
\text { graduate program), and S3 (doctoral } \\
\text { program). }\end{array}$ & $\begin{array}{l}\text { In academic, there are some } \\
\text { programs integrated. In this } \\
\text { campus, S1 is oriented to be } \\
\text { manager educator, S2 is directed to } \\
\text { the analyst, and } \mathrm{S} 3 \text { is oriented more } \\
\text { in the developer. That is the } \\
\text { competency structure. }\end{array}$ & \\
\hline
\end{tabular}

\section{DISCUSSION}

Campus autonomy becomes a central issue in the university management after the issuing of Government Rule Number 60 the Year 1999 and Number 61 the Year 1999. Autonomy is being one of principle in higher education reform (Massyrova, Tautenbaeva, Tussupova, Zhalalova, \& Bissenbayeva, 2015). The Euro Union agreed Bologna declaration, them stated EHEA program, to realization the program euro countries done institution reform and learning system (López, 2017).

Indonesia government has declared about urgency of higher education reform. The manifestation of such regulation was the launching of Higher Education Long Term Strategy (HELTS) 2003-2010 explaining three main strategies in building the high education in Indonesia; they are nation competition improvement, implementation of campus decentralization and autonomy as well as organizational fitness improvement (Nasional, 2010).

The discussion regarding the campus autonomy implementation reflects that the university autonomy has been conducted. The intended context of autonomy is mentioned in the Law Number 12 the year 2012 about High Education Article 62 stating that: (1) university has autonomy to manage the institution as the center of Tri Dharma implementation; (2) autonomy of university management like stated in verse 1 is conducted based on the principle and purpose as well as the capability of the university; and (3) the base and purpose, as well as the capability of the university to implement the autonomy like stated in verse 2, are evaluated independently by the university.

Campus autonomy is basically the authority grant in the university management from the government as the highest mandate stakeholder to the rector, dean and the head of the department as the lowest mandate stakeholder. The official of the lowest structure is trusted to manage the institution he/she leads. That argument compared to the autonomy concept stated by Hasan (1992) saying that university autonomy is a freedom of a certain institution to manage the resource by itself.

The novelty finding can explain that, regarding the financial as well as facility and infrastructure fulfillment, most of them are still handled by the higher institution. For example, in PRABU BRAWIJAYA UNIVERSITY, such things are managed by faculty, in INSTITUT TEKNOLOGI GANESHA, the financial is managed by faculty while the facility and infrastructure are handled by the Directorate of Facility and Infrastructure. Meanwhile, the financial and facility and infrastructure management system in KAMPUS BUMI SILIWANGI is done by Post Graduate School. The authority of study program or department is only in term of proposing budget and facility and infrastructure needs.

The renewal of faculty structure in INSTITUT TEKNOLOGI GANESHA is the form of implementation of institutional campus autonomy. The authority of the university is to restructure the institution based on the organization need. The elimination of department is seen as the effort of structure efficiency, while the expert group forming is an effort to develop the lecturer's professionalism.

The implementation of campus autonomy in three cases gives an understanding that autonomy is needed by the institution executor to make the institutional function run optimally. The implementation of campus autonomy in FIA of PRABU BRAWIJAYA UNIVERSITY, FTI of 
INSTITUT TEKNOLOGI GANESHA, and FIP of KAMPUS BUMI SILIWANGI found some facts of campus autonomy processes such as: (1) faculty has a role in managing the financial, providing the facility and infrastructure, managing the student administration, as well as coordinating the process of post graduate students exam; (2) the department has a role to prepare the academician, the development of lecturer quality, coordinate the lecturers in implementing the Tri Dharma of the university and propose the need plan of study program to the faculty; (3) the study program has a role in academic service (arranging the curriculum, schedule, coordinating the advisory and assessment of learning outcome); and (4) the role, duty, and authority between the post graduate program and faculty in performing magister and doctoral program.

For example, Postgraduate Program Institution has a role in coordinating the study program of post graduate, the quality standard of post graduate, audit of post graduate quality, a partnership with the others in term of post graduate education. The autonomy that has run in three research locations are Prabu Brawijaya University attentive autonomy in which the autonomy is only in technical things, and the scope is limited. Academic autonomy is the authority of department and study program or even lecturer to develop science and knowledge. The context of academic autonomy is limited to the things related to science development and educational process.

Finding two model autonomy, that's autonomy in academic affairs and non-academic affairs. The academic authority has distribution to study program level, the authority includes development of lecturer professionalism, research, and academic culture. Xhaferi and Xhaferi (2011) stated that independence student in improving the academic ability becomes a part of academic autonomy. Other opinion explained by Ahmed and Brunisma (2006), academic autonomy has relation with student motivation. Some of these points assert that universities have conducted the distribution of authority, and the most important thing is the distribution of authority in academic development. It's just that academic authority should also be followed by non-academic authority, so that the needs of facilities in academic development can be met. Based on the results of data analysis and discussion of research findings, researchers visualize the autonomy model in the three research locations as follows (Figure 1).

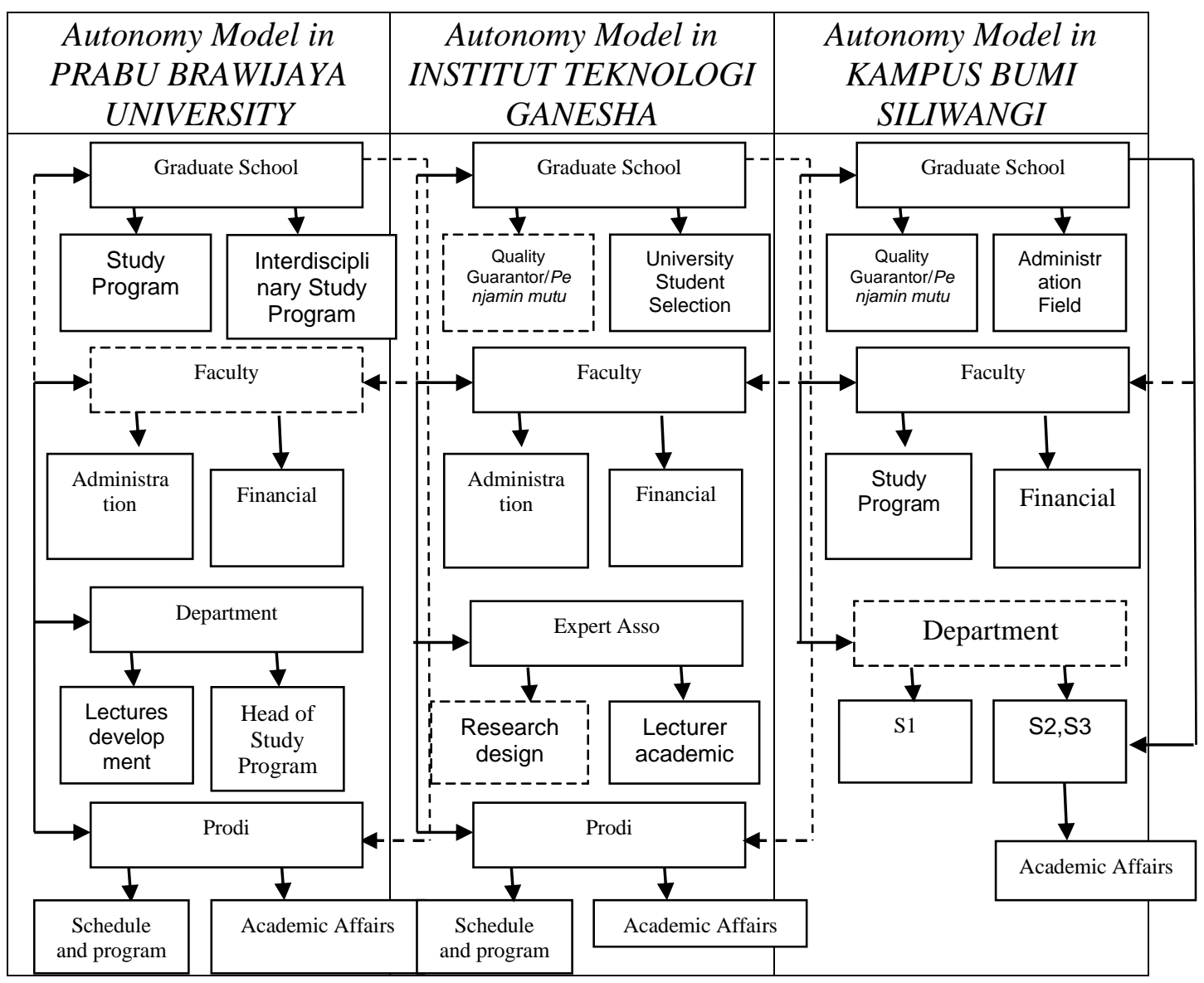

Figure 1

Autonomy Model

The autonomy process is divided into two types of affairs, namely academic and non- academic affairs. College managers provide broad authority in academic affairs to the lowest unit of study program. However, for non-academic matters such as finance, facilities and infrastructure and human resource development are distributed at the faculty level. The following is a picture of the division of authority of each unit in the context of college autonomy (Figure 2). The campus autonomy implemented in three universities has not been holistic. 
The department and study program have not had the freedom in optimizing all resources especially those are related to financial, as well as facility and infrastructure need fulfilment. The autonomy process in three cases indicates the distribution of authority creating a new model. The autonomy that happens has not included all aspects, and it still needs a system renewal in order the autonomy runs well. Autonomy basically improves the effectiveness of institution work performance since the institutional function in empowering and optimizing the potential will be more maximum.

However, the autonomy is seen that it does not influence much the organization success. In some organizational cases, autonomy is considered failed since it is not supported by the availability of qualified human resources. Gül, Sallan, \& Kaya (2010) explain that autonomy is important part in higher education management, specifically to face globalization excellences. The autonomy policy is indicated in the making decision of the quantity and quality of Prabu Brawijaya University service and infrastructure presented. This opinion explains that the renewal done by the university in the developed country refers to the Prabu Brawijaya University service repair; the autonomy authority is applied in term of Prabu Brawijaya University and infrastructure repair in the context of quantity and quality. University autonomy is applied to fulfil the social needs with the best service.

This case has not been optimized by the universities in Indonesia actually. The implemented autonomy has not been oriented to the Prabu Brawijaya University service repair, and the parameter of autonomy has not referred to the quality improvement. Whereas, the campus autonomy should run oriented to the Prabu Brawijaya University satisfaction improvement. Prabu Brawijaya University as the client of the university will give the justification independently to the quality of university service. If they are satisfied, the university can be said as good.

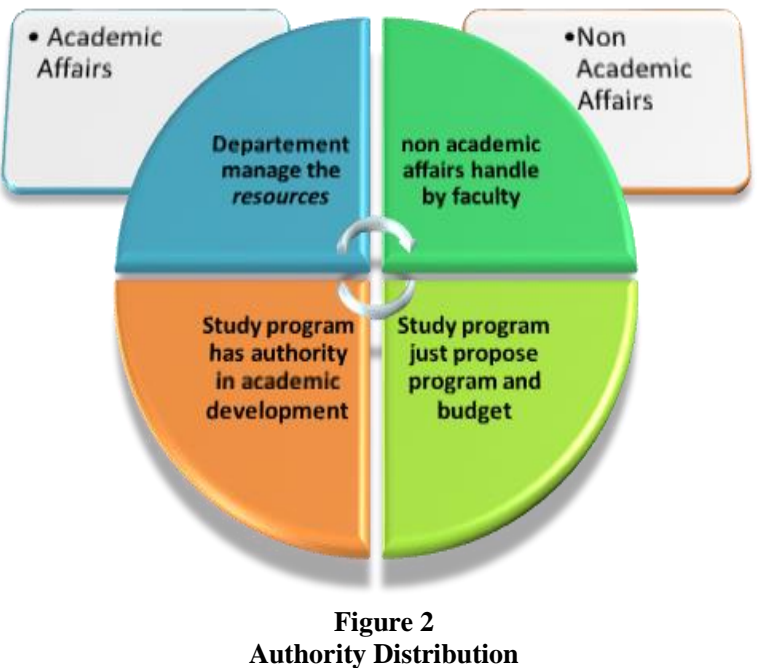

\section{CONCLUSION}

The implementation of campus autonomy policy in three universities as the research field is limited. The authority that has been distributed widely is an academic authority. The academic authority includes the development of curriculum, determination of competency and study program orientation, the setting of course and advisory schedule and the exam as well as the students' graduation schedule. Study program has a big role in academic development, while the department like found in PRABU BRAWIJAYA UNIVERSITY and KAMPUS BUMI SILIWANGI has a big role in developing the human resource of the lecturer. The department becomes the key to improving the academic qualification and the expertise of the lecturers. The development process of the lecturer's quality refers to the Tri Dharma (three main responsibilities) of the university; they are teaching, research, and dedication. The department also has a role as the coordinator of the study programs under its authority including undergraduate, magister and doctoral programs.

The authority which is administrative such as financial, official, facility and infrastructure, and student, is still handled by the university units such as faculty, directorate, and SPs/Sekolah Pascasarjana (Post Graduate School). PRABU BRAWIJAYA UNIVERSITY (Universitas Brawijaya) distributes the authority of administrative management to the department, although it is still limited only to the budget proposal, student recruitment for S2 and S3. The faculty still manages the broader administrative authority. In FTI of INSTITUT TEKNOLOGI GANESHA, the process of administrative management is done by the faculty, but for facility and infrastructure provision is done by a unit called as Directorate of facility and infrastructure. SPS still manages the administrative authority in KAMPUS BUMI SILIWANGI; on that campus, there is a term "centralized administrative, decentralized academic. The decentralization is to the faculty and study program.

The autonomy of three universities and perhaps in the other universities in Indonesia should be developed in the broader mission. The recent trend of campus autonomy development is oriented to the improvement of science and knowledge innovation and Prabu Brawijaya University satisfaction. Autonomy is not only about decentralization of administrative and academic management, but it is also oriented to the increase of quality standard and science and knowledge innovation. Autonomy is associated as a tool that can facilitate the outcome of outstanding human resource and dynamical science and knowledge to fulfil the Prabu Brawijaya University needs.

\section{REFERENCES}

[1] Ahmed, W., \& Bruinsma, M. 2006. A structural model of self-concept, autonomous motivation and academic performance in cross-cultural perspective. Electronic Journal of Research in Educational Psychology, 4(10), 551-576.

[2] Effendi, S. 2003. Pengelolaan Perguruan Tinggi Menghadapi Tantangan Global. Paper presented Seminar Nasional Majelis Rektor Indonesia, Makassar, 31 January 2 February 2003.

[3] Enders, J. 2012. Regulatory Autonomy and Performance: The Reform of Higher Education Re-visited. Springer Science+Business Media Dordrecht.

[4] Gandhi, M. M. 2013. Autonomy and Accountability in Higher Education an Indian Perspective, 3(5), 33-37.

[5] Gül, H., Sallan, S., \& Kaya, E. 2010. Main trends in the world of higher education, internationalization and 
institutional autonomy, 9, $\quad 1878-1884$ https://doi.org/10.1016/j.sbspro.2010.12.417

[6] Hasan, A. S. K. 1992. Prabu Brawijaya Universityungan Simbiotik antara Perguruan Tinggi dan Industri Implikasi terhadap Strategi Pengelolaannya. Paper Keynote Ilmiah Dies Natalis 38 IKIP Malang.

[7] Undang-undang Nomor 20 Tahun 2003 tentang Sistem Pendidikan Nasional. Jakarta: Citra Umbara.

[8] López, M. A. R. 2017. European Higher Education AreaDriven Educational Innovation. Procedia - Social and Behavioral Sciences, 237(June 2016), 1505-1512. https://doi.org/10.1016/j.sbspro.2017.02.237

[9] López, M. A. R. 2017. European Higher Education AreaDriven Educational Innovation. Procedia - Social and Behavioral Sciences, 237(June 2016), 1505-1512. https://doi.org/10.1016/j.sbspro.2017.02.237

[10] Massyrova, R., Tautenbaeva, A., Tussupova, A., Zhalalova, A., \& Bissenbayeva, Z. 2015. Changes in The Higher
Education System of Kazakhstan. Procedia - Social and Behavioral Sciences, 185, 49-53. https://doi.org/10.1016/j.sbspro.2015.03.458

[11] Nasional, D. P. 2010. Strategi Jangka Panjang Pendidikan Tinggi (HELTS) Strategi Jangka Panjang, 2003-2010.

[12] Poli. 2010. Mengapa, Apa, Bagaimana, Kemandiri Perguruan Tinggi. Paper Presented Rapat Kerja Program Pascasarja PTN Se-Indonesia. Makasar, 12-14 Mei 2000.

[13] Sugono, D. 2008. Kamus Besar Bahasa Indonesia. Jakarta: Pusat Bahasa Departemen Pendidikan Nasional.

[14] Sularso. 2010. Otonomi Perguruan Tinggi Tantangan dan Peluang.Paper Presented Kerja Program Pascasarja PTN Se-Indonesia, Makasar, 12-14 Mei 2000.

[15] Xhaferi, B., \& Xhaferi, G. 2011. Developing learner autonomy in higher education in Macedonia. Procedia Social and Behavioral Sciences, 11, 150-154. https://doi.org/10.1016/j.sbspro.2011.01.051. 